\title{
TRACING OF BIOSURFACTANT SYNTHESIZING GENES IN BACILLUS SP., BY IN VITRO AND IN SILICO TECHNIQUES USING SRFA GENE AS MARKER
}

\author{
Saravanakumari $\mathbf{P}^{*}$, Nirosha $\mathbf{P}^{1}$ \\ *Dept. of Biotechnology, Sree Narayana Guru College, Coimbatore, India \\ ${ }^{1}$ Department of Microbiology, Dr. G R Damodaran College of Science, Coimbatore, India \\ *Corresponding Author's Email: sarankumaribs@gmail.com
}

Received 08 August 2012; Review Completed 26 Aug 2012; Accepted 04 Sep 2012, Available online 15 Sep 2012

\begin{abstract}
Biosurfactant production enhances the establishment of bacteria in its environment. It was confirmed among the food borne pathogens of Bacillus cereus, B. licheniformis and B. subtilis isolated from spoiled dairy products. Molecular weights of the purified DNA from these isolates were determined as $>4000 \mathrm{~Kb}$. Restriction digestion of extracted genomic DNA by EcoRI and HindIII and amplification by genus specific 16S rRNA derived primer confirmed the homology among all. Production of biosurfactant by these bacteria was confirmed by drops collapse test, reduction in surface tension of culture media and emulsification properties. Purified biosurfactants from these isolates were characterized as surfactin, lichenysin and plipastatin from $B$. subtilis, B. licheniformis and $B$. cereus respectively. BLAST analysis of surfactin synthesizing gene srfA from $B$. subtilis showed $80 \%$ similarity with surfactant coding gene of lichenysin in B. licheniformis, $76 \%$ similarity with an unknown non-ribosomal peptidyl protein and $73 \%$ with bacitracin synthetase in B. cereus. So, the unknown plipastatin coding genes in $B$. cereus predicted as a non-ribosomal in origin and have antimicrobial properties.
\end{abstract}

Key words: Bacillus, Emulsification, Surfactant, Surfactin synthesizing genes.

\section{INTRODUCTION}

Extreme usage of chemical surfactants in industries and discharge of such chemical wastes into the environment leads to the unwanted changes in the ecosystem. Biological alternative to use of such harsh chemical is the biosurfactants that are required for many industrial processes such as foaming, wetting, washing, emulsification, and phase separation. Other advantages of using biosurfactants are their ecological acceptance owing to their lower toxicity, biodegradability and specificity ${ }^{1}$. So, the increasing industrial demand for the biosurfactants requires the large-scale production of biosurfactants using microorganisms. Improved production of biosurfactant in microorganisms can be achieved by gene amplification.

Biosurfactants are synthesized through series of enzymatic cascade and these enzymes are coded by cluster of genes ${ }^{2}$. For cloning and improved production, entire set of genes coding for biosurfactant must be known. In many efficient producers, genes involved in biosurfactants synthesis are not completely known.

One of the major biosurfactant-producing organisms belongs to the genus Bacillus ${ }^{3}$. The genus Bacillus is common food spoilage causing bacteria; representative species are B. licheniformis, B. subtilis and B. cereus. Biosurfactants production among these species enables them in coordinated way of establishment in the contaminated food through biofilm formation and emulsification of food. Researchers recognized that in biofilm, biosurfactants maintains channels between multicellular structures and in dispersal of cells through quorum sensing ${ }^{4}$.

B. subtilis produces a known lipopeptide biosurfactant called as surfactin, which is coded by four open reading frames (ORFs) named as $\operatorname{srfA}, \operatorname{srfB}, \operatorname{srfC}$ and $s r f D^{5}$.
Similarly, lichenysin is a lipopeptide biosurfactant produced by $B$. licheniformis coded by lichenysin operon (lchA) consists of three peptide synthetase genes licAA, lic $A B$, lic $A C$ and $l i c A D^{6}$. B. cereus produces a lipopeptide biosurfactant called plipastatin ${ }^{7}$. But biosurfactant plipastatin coding genes in B. cereus is still under study.

The present work has been carried out to establish the role of biosurfactant produced by food spoilage causing genus Bacillus and deducing the genes coding for biosurfactant especially plipastatin by comparing the similarity between biosurfactants genes of $B$. licheniformis and B. subtilis using in silico technique.

\section{MATERIALS AND METHODS}

\section{Isolation and identification of Bacillus}

Spoiled, canned dairy product was collected, homogenized and about $10 \mathrm{~g}$ of homogenized sample was inoculated in $100 \mathrm{ml}$ of minimal media with $2 \%$ paraffin as carbon source. After $48 \mathrm{~h}$ of incubation, inoculum was spread over minimal agar media. The plates were incubated at room temperature for $24 \mathrm{~h}$. Morphologically distinct colonies were isolated and sub-cultured. Isolates were subjected to microscopic, specific biochemical and metabolic characterization tests following the procedures of Bergy's classification system ${ }^{8}$.

\section{Measurement of biosurfactant activity}

Isolates were sub-cultured on minimal medium and biosurfactant activities of the isolates were determined qualitatively by drops collapse test ${ }^{9}$. Quantitative surfactant activities were determined by burette method and emulsification properties by emulsification activity and emulsification index ${ }^{10}$.

Structural characterization of the biosurfactants 
Biosurfactants produced by each isolate was purified from the culture supernatants prepared by centrifuging the culture broth at $12000 \mathrm{rpm}$ for $30 \mathrm{~min}$ at $4^{\circ} \mathrm{C}$. Then it was mixed with methanol $(2: 1)$ and incubated overnight at $4^{\circ} \mathrm{C}$. After incubation, precipitated biosurfactants was collected by centrifugation at $6000 \mathrm{rpm}$ for $15 \mathrm{~min}$ at $4^{\circ} \mathrm{C}$. Biosurfactants were further purified by extraction with 250 $\mu \mathrm{l}$ of chilled acetone. Ionic nature of the purified biosurfactants was determined ${ }^{11}$.

Presence of lipids in the purified biosurfactants were confirmed by TLC using the solvent system hexane: petroleum ether: acetic acid (60:40:1) and iodine vaporization. Amino acids in the peptides of biosurfactants were hydrolysed by boiling with $6 \mathrm{~N} \mathrm{HCl}$ for $6 \mathrm{~h}$ and the content was run in TLC using a solvent system of butan-1ol: acetic acid: water (80:20:20) and ninhydrin reagent was used as a detecting agent. Protein content in each sample was estimated by Lowry et al. method ${ }^{12}$.

\section{Invitro analysis of biosurfactants synthesizing genes}

Genomic DNA was isolated from the Bacillus sp. by enzymatic hydrolysis of cell wall, extraction by chloroform - isoamylalcohol (24:1) mixture and purification by $70 \%$ of ethanol. The purified DNA ( $2 \mu \mathrm{l}$ of each) was subjected to restriction by restriction enzymes of $1 \mu \mathrm{l}$ Eco RI and $1 \mu \mathrm{l}$ Hind III in $2.5 \mu \mathrm{l}$ of $10 \mathrm{X}$ TE buffer. The mixtures were incubated at varying temperatures of $37^{\circ} \mathrm{C}$ for $2 \mathrm{~h}, 65^{\circ} \mathrm{C}$ for $2 \mathrm{~h}$ and $70^{\circ} \mathrm{C}$ for $20 \mathrm{~min}$ and stored at $4^{\circ} \mathrm{C}$. Then the products were amplified by PCR using the primer derived from $16 \mathrm{~S}$ rRNA sequence of $B$. circulans (Gen Bank accession No: X60613) for selective amplification of DNA of Bacillus sp. from mixed samples. It can amplify 546 bp of sequence ${ }^{13}$.

\section{Primer type Primer Sequence}

BCF1 CGGGAGGCAGCAGTAGGGAAT

\section{BCR2 CTCCCCAGGCGGAGTGCTTAAT}

The PCR product was visualized in $2 \%$ agarose gel electrophoresis applying an electric current of 50V. Sizes of the PCR products were determined by comparing with a narrow range DNA ladder in agarose gel electrophoresis.

Table 1: Biosurfactant activities of bacterial isolates

\begin{tabular}{|c|c|c|c|}
\hline Organisms & EA $(\mathbf{O D}$ at $610 ~ \mathbf{~ m})$ & EI $(\%)$ & Surface tension $\left(\mathbf{N m}^{-\mathbf{1}}\right)$ \\
\hline Bacillus cereus & 0.035 & 70 & $\mathbf{0 . 3 9}$ \\
\hline B. licheniformis & 0.064 & 59 & $\mathbf{0 . 3 1}$ \\
\hline B. subtilis & 0.045 & 67 & $\mathbf{0 . 3 0}$ \\
\hline control & 0.000 & 00 & $\mathbf{0 . 7 2}$ \\
\hline
\end{tabular}

\section{In silico analysis of biosurfactants synthesizing genes}

The surfactin synthetase gene, srfA (X65835) is 865 bp in length. It is involved in the synthesis of biosurfactant surfactin in B. subtilis $^{5}$ and retrieved from GenBank. A basic local alignment search (BLAST 2.2.24) was performed for srfA gene with genomic DNA of B. cereus AH820 (NC_011773) and B. licheniformis ATCC14580 (NC_006270).

\section{RESULTS AND DISCUSSIONS}

\section{Assay of biosurfactant activity}

Food spoilage causing bacteria establishes in the food and resists the attack by chemical preservatives through the biofilm formation. Bacterial cells in biofilm communicate in more complex patterns of co-operative behavior that are termed as 'quorum sensing', bacterial cell-to-cell communication which is attributed by biosurfactants ${ }^{14}$. Biosurfactants also enables the bacterial population to trigger a unified response that is advantageous to its survival. This response improves access to complex nutrients or environmental niches and develops collective defense mechanisms against alternative competitive microorganisms or agents 15 .

Biosurfactants production by $B$. cereus, B. licheniformis and $B$. subtilis isolated from biofilm of spoiled food were confirmed by collapsing of drop within a minute in drops collapse test. Culture supernatant from isolates, collapsed/emulsified the water droplet on a mineral oil platform within $10 \mathrm{sec}$. Surfactant present in the drop spreads or collapses the drop by force or reduction in interfacial tension between the liquid drop and the hydrophobic surface. The stability of drops is dependent on surfactant concentration and correlates with surface and interfacial tension ${ }^{16}$. As the time required for collapsing and surfactant concentrations are indirectly correlated, collapsing of drop within $10 \mathrm{sec}$ confirmed presence of higher concentration of biosurfactant by all the isolates.

Surfactant and emulsification activities of the isolates were tabulated in table 1. Results showed that surface tensions of culture media were reduced from $0.072 \mathrm{~N} / \mathrm{m}$ to less than $0.040 \mathrm{~N} / \mathrm{m}$ and formed stable emulsion of above $60 \%$. The efficient surfactant and emulsification properties of the purified biosurfactants of these isolates confirmed it's foaming, wetting, washing and emulsification properties needed for industrial processes.

\section{Structural characterization of the biosurfactants}

White, powdery biosurfactant of $10 \mathrm{mg} / \mathrm{ml}$ of media was purified from B. subtilis and B. cereus and $20 \mathrm{mg} / \mathrm{ml}$ of media from $B$. licheniformis. Based on the formation of line of precipitation, ionic natures were determined as zwitter ionic in B. subtilis, anionic in B. cereus and cationic in B. licheniformis. Development of yellow colour positive bands confirmed the presence of lipids in lipid chromatography, but $\mathrm{R}_{\mathrm{f}}$ values of bands varied with each sample due to the linkage of peptides with varying length of fatty acids. Presence of amino acids valine, isoleucine, leucine and asparagine were confirmed using nin-hydrin in TLC plates and further by development of colour in Lowry et al. assay. So, the purified biosurfactants from the 
isolates were confirmed as lipopeptides. The results of above experiments were tabulated in table 2 .

Presence of valine, isoleucine, leucine and asparagine in purified biosurfactants confirmed as surfactin in B. subtilis, which is a cyclic lipoheptapeptides consists of (LGlutamine --> (L - Leucine $)_{2}-->$ Valine --> L - Aspartic acid --> D - Leucine --> L - Leucine --> L - Valine -->
L- Isoleucine) and $\beta$ - hydroxy fatty acid ${ }^{17}$. Lichenysin is a similar biosurfactant produced by $B$. licheniformis differs by the presence of isoleucine in the $\mathrm{C}$-terminal end instead of leucine and asparagines residue instead of aspartic acid in the surfactin peptide ${ }^{18}$. Plipastatin is a lipopeptides biosurfactant produced by $B$. cereus ${ }^{7}$.

Table 2: Characters of biosurfactants purified from bacterial isolates

\begin{tabular}{|l|l|ll|l|}
\hline Bacterial source of biosurfactant & $\boldsymbol{R}_{\boldsymbol{f}}$ values for lipid & Con. of $\quad$ protein $(\boldsymbol{\mu g} / \mathbf{m l})$ & Ionic detection \\
\hline Bacterial source of biosurfactant & $\boldsymbol{R}_{\boldsymbol{f}}$ values for lipid $(\mathbf{c m})$ & Con. of $\quad$ protein $(\boldsymbol{\mu g} / \mathbf{m l})$ & Ionic detection \\
\hline B. cereus & 0.48 & 0.29 & Anionic \\
\hline B. licheniformis & 0.58 & 0.30 & Cationic \\
\hline B. subtilis & 0.12 & 0.21 & Zwitterion \\
\hline
\end{tabular}

\section{DNA analysis}

DNA isolated from B. cereus, B. licheniformis and $B$. subtilis showed molecular weights above $4000 \mathrm{~Kb}$. Extracted genomic DNA were subsequently subjected to restriction digestion and the products were amplified in PCR using genus specific primers. So that isolated bacterial genus Bacillus was characterized using the combination of culture and non-culture techniques for confirmation of homology among isolated genus Bacillus ${ }^{19}$. Restricted products of genomic DNA from each isolate resulted in similar banding pattern (100 bp in length) (Fig. 1), which confirmed that surfactant-synthesizing genes are not interfering in genus specific genes and are not interfered by the restriction digestion by EcoRI and HindIII.

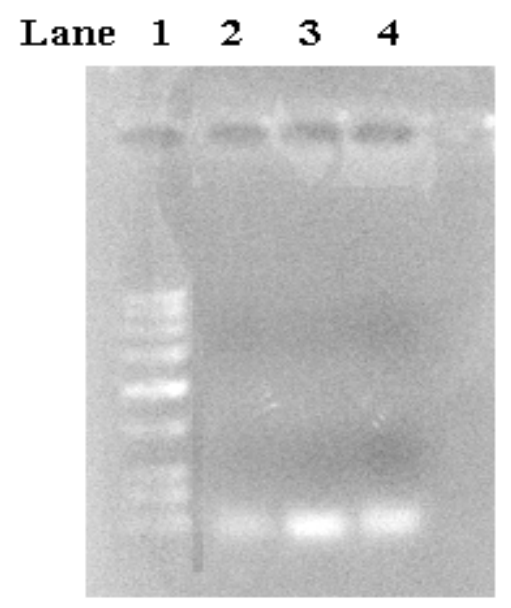

\section{In silico analysis of biosurfactants synthesizing genes}

The BLAST result of srfA with $B$. licheniformis ATCC14580 (NC_006270) showed 83\% similarity with $l \operatorname{ch} A A$ gene and $7 \overline{2} \%$ of similarity with $l \operatorname{ch} A B$. Similarly, $76 \%$ of similarity with non-ribosomal peptidyl synthetase protein coding gene, $76 \%$ of similarity with long chain fatty acid CoA ligase gene and $73 \%$ of similarity with bacitracin synthetase 1 gene of $B$. cereus AH820 (NC_011773). So, the surfactin and lichenysin coding gene clusters are quite similar. Whereas, in B. cereus, showed identity with bacitracin (an antibiotic) synthetase gene. So the biosurfactant plipastatin may have antimicrobial activity and can control bacteria and viruses through disruption of cell membrane through physiochemical interaction ${ }^{20}$ and is non-ribosomal in origin.

\section{Lane1: Low Range DNA Ruler}

Lane 2: Digested \& amplified DNA of Bacillus subtilis

Lane 3: Digested \& amplified DNA of B.licheniformis

Lane 4: Digested \& amplified DNA of B. cereus

Figure 1: PCR amplified restricted DNA

\section{CONCLUSION}

The food-spoilage causing genus Bacillus produces lipopeptide biosurfactants. That enables in establishment of bacterial cells in denser media and competitively inhibits the growth of other population. Purified lipopeptide biosurfactants were recognized as surfactin, lichenysin and plipastatin from B. subtilis, B. licheniformis and $B$. cereus respectively. DNA isolated from these isolates showed homology and from the known $\operatorname{srf} A$ of $B$. subtilis, the unknown plipastatin coding genes in $B$. cereus was identified as non-ribosomal in origin and has antimicrobial properties. Thereby concludes that lipopeptide surfactants produced by the bacterial genus Bacillus presents a great potential for pharmaceutical and industrial application. The knowledge of gene clusters coding for the biosurfactants paves the new way to develop recombinants for the overproduction of biosurfactants to meet the industrial needs. 


\section{REFERENCES}

1. Karanth NGK, PG Deo and NK Vennanadig, Microbial 11. Meylheuc T, Van Oss CJ, Bellon-Fontaine MN, Adsorption of production of biosurfactants and their importance, Curr. Sci., 1999, 77: $116-126$.

2. Ochsner UA, J Reiser, Armin Fiechter, and Bernard Witholt, Production of Pseudomonas aeruginosa Rhamnolipid Biosurfactants in Heterologous Hosts. Appl. Environ. Microbiol., 1995, 61(9): 3503-3506.

3. Pirttijärvi TSM, Graeffe TH and Salkinoja-Salonen MS, Bacterial contaminants in liquid packaging boards: assessment of potential for food spoilage. Journal of Applied Bacteriology, 1996, 81: 445-458.

4. Sünje Johanna Pamp and Tim Tolker-Nielsen, Multiple Roles of Biosurfactants in Structural Biofilm Development by Pseudomonas aeruginosa. J. Bacteriol., 2007, 189(6): 25312539.

5. Peypoux F, Bonmatin JM and Wallach J, Recent trends in the biochemistry of surfactin. Appl. Microbiol. Biotechnol., 1999, 51(5): $553-563$.

6. Marahiel, MA, Konz D, and Dokel S, Molecular and biochemical characterization of the protein template controlling biosynthesis of the lipopeptide lichenysin of Bacillus licheniformis. J. Bacteriol., 1999, 181: 133-140.

7. Nishikiori $T$, Naganawa $H$, Muraoka $Y$, Aoyagi $T$ and Umezawa H, Plipastatins: new inhibitors of phospholipase A2, produced by Bacillus cereus BMG302-fF67. II. Structure of fatty acid residue and amino acid sequence. J. Antibiot., 1986, 39: 745-754.

8. Bergey, DH. (David Hendricks), Bergy's manual of determinative bacteriology. $3^{\text {rd }}$ ed. Schema for identification of bacteria. Published by Cole-Parmer, 1993.

9. Youssef NH, Duncan KE, Nagale DP, Savage KN, Knapp $\mathrm{RM}$, and McInerney MJ, Comparison of methods to detect biosurfactant production by diverse microorganisms. J. Microbiol. Meth., 2004, 56: 339 - 347.

10. Kim CH, Kim JN, Ha SG, Yun and Lee SS, Effects of dietary addition of surfactant Tween 80 on ruminal fermentation and nutrient digestibility of Hanwoo steers, Asian-australas, 2004, 17: $337-342$. biosurfactant on solid surfaces and consequences regarding the bioadhesion of Listeria monocytogenes LO28, Journal of Applied Microbiology, 2001, 91: 822-832.

12. Lowry OH, Rosebrough NJ, Farr AL, and Randall RJ, Protein measurement with the folin-phenol reagent, J. Biol. Chem., 1951, 193: $265-275$.

13. Raul J Cano, Monica K Boruki, Mary Highy Schweitzer, Bacillus DNA in Fossil Bees: an ancient Symbiosis?. Appl. Environ. Microbiol., 1994, 60(6): 2164 - 2167.

14. Morten Hentzer, Kathrin Riedel, Thomas B. Rasmussen, Inhibition of quorum sensing in Pseudomonas aeruginosa biofilm bacteria by a halogenated furanone compound, Microbiology, 2002, 148: 87-102.

15. Jiménez-Gómez P, MJ. Pozuelo de Felipe, F. Llinares Pinell, JE, García de los Ríos, Quorum-sensing in Pseudomonas aeruginosa and Salmonella: Active natural compounds as antagonists, Communicating Current Research and Educational Topics and Trends in Applied Microbiology, 2007, 41- 52.

16. Jain D, Collins-Thompson D, Lee H, A drop-collapsing test for screening surfactant-producing microorganisms, J. Microbiol Methods, 1991, 13(4): 271-279.

17. Joachim Vater, Barbel Kablitz, Christopher Wilde, Peter Franke, Neena Mehta and Swaranjit Singh Cameotra, Applied and Environmental Microbiology, 2003, 6210 - 6219.

18. Yakimov MM, Timmis KN, Wray V, and Fredrickson HL, Characterization of a new lipopeptides surfactant produced by thermotolerant and halotolerant subsurface Bacillus licheniformis BAS 50. Appl. Environ. Microbiol., 1995, 61: $1706-1713$

19. Oguntoyinbo FA, Monitoring of marine Bacillus diversity among the bacteria community of sea water. African Journal of Biotechnology, 2006, 6 (2): 163-166.

20. Ligia Rodrigues, Ibrahim M. Banat, Jose Teixeira and Rosario Oliveira, Biosurfactants: potential applications in medicine, Journal of Antimicrobial Chemotherapy, 2006, 57 (4): 609 618. 